\title{
VIOLENCE AGAINST WOMEN IN LAW SCHOOLS
}

\section{TERESA SCASSA*}

In her article. Scassa discusses the existence of a pattern of violence against women in society generally and in law schools specifically. She examines threats and acts of discrimination that have been experienced by both women who are teachers and women who are students in law schools across Canada. By exploring and defining the concept of violence, Scassa demonstrates how accepted. commonplace events that occur within law school walls are indeed acts of violence which must be recognized as such and dealt with accordingly. Scassa argues that through a pattern of harassmem. women have been silenced and that this "silencing" is a form of violence that must be stopped.
Scassa examine les comportemens violents qui se manifestent dans la société én général et dans les facultés de droit plas précisément. Elle examinc les manaurres dintimidation et les actes discriminatoires que subissem à la fois les professcures et les énudiantes des facultés de droit partout an Canada. En analysant et en définissamt le concept de la violence. Scassa démontre à quel point ces agissements somt acceptes et font partic du quoridien des facultés de droit. Elle nous exhorte à recommaîre quil s'agit bel et bien d'actes de violence et à les traiter en conséquence. Scassa affirme que, à force de harcèlement. les femmes ont été réduites au silence et que ce silence est en himême unc forme de violence qui doit cesser.

\section{TABLE OF CONTENTS}

I. INTRODUCTION $\ldots \ldots \ldots \ldots \ldots \ldots \ldots \ldots \ldots \ldots \ldots$

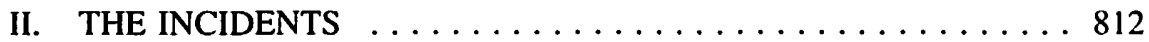

III. VIOLENCE $\ldots \ldots \ldots \ldots \ldots \ldots \ldots \ldots \ldots \ldots \ldots \ldots \ldots$

IV. SILENCE AND VIOLENCE $\ldots \ldots \ldots \ldots \ldots \ldots \ldots \ldots \ldots . \ldots 21$

V. VIOLENCE AND THE SEXUALIZATION OF WOMEN $\ldots \ldots 823$

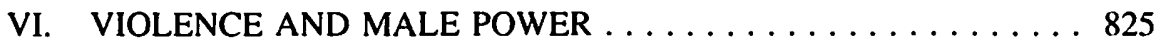

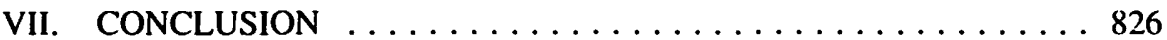

It's the little violences

You're not sure when it will happen.

You're not sure who will do it.

All you know is that it will happen.

It happens when the man who sits across from you in criminal law class gives a hypothetical about rape

and he uses the first person.

(Woman law student. 1991).

This paper is dedicated to the memory of my close friend and colleague Patricia Allen.

Assistant Professor of Law, University of Dalhousic. I would like to thank Rod Macdonald. Audrey Macklin, William Miller, Rick Pildes, Colleen Sheppard. Martha Shaffer and Maureen Duffy for their comments and criticisms of earlier drafts of this paper. This paper was prepared with the assistance of the Social Sciences and Humanities Research Council of Canada. 


\section{INTRODUCTION}

On December 6, 1989, 14 women engineering students at the Ecole Polytechnique of the Université de Montréal were gunned down by a man who singled them out from male students in the classroom and whose last words to them accused them of being "a bunch of feminists." Through the shock of the incident, women across Canada joined rallies to commemorate the victims. They tried to place the slayings in the context of what they perceived to be a pattern of violence against women in our society. In their view, the massacre was more brutal, bloody and public than most manifestations of misogynistic violence, but it was not an incident in isolation. ${ }^{2}$

The reactions of these women, and their attempt to equate the Ecole Polytechnique incident with experiences of violence in their own lives were met with hostility by some, mostly men, who refused either to believe in the existence of patterns of violence against women, or to believe that this brutal outburst of misogyny was anything but the random act of a madman. These critics maintained that either what these women were talking about was not violence or that it was not gender-related. ${ }^{3}$

I write this paper in the context of both the massacre of the fourteen women students, and the backlash against those who attempted to articulate a link between that incident and the daily violence they face as women in this society.

1. $\quad$ Montreal Gunman Kills 14 Women and Himself" New York Times (7 December 1989) A23.

2. See, for example: H. Bauch, "Wounded" Montreal Gazette (9 December 1989) B I: "The response from most women, and not only professed feminists, was that this was not an isolated incident, but the ultimate upshot of a deep-rooted male hostility toward women that permeates our society."; see also: M. Lamey, "Anti-woman and anti-feminist sentiments arc all around us" The Montreal Gazette (9 December 1989) B1; "Control the Guns" Montreal Gazefte (9 December 1989) B2; D. Macpherson "Massacre reveals stark face of fear" Montreal Gazette (9 December 1989) B3; K. Dunn "Fear is legacy women share after killer's fury is spent" Montreal Gazette (9 December 1989) A1; T. Wills, "PM deplores violence against women as MPs demand action" Montreal Gazette (9 December 1989) A4.

3. The same process of immediate identification of delibcrate violence by members of the target group and strong rejection of such deliberateness by members of the dominant or non-target groups is observed by $\mathrm{M}$. Matsuda in the case of racist speech:

The typical reaction of target-group members 10 an incident of racist propaganda is alarm and immediate calls for redress. The typical reaction of non-target group members is to consider the incidents isolated pranks, the product of sick-but-harmless minds. This is in part a defensive reaction: a refusal to believe that real people, people just like us are racists. This disassociation leads logically to the claim that there is no institutional or state responsibility to respond to the incident." (M.J. Matsuda, "Public Responses to Racist Speech: Considering the Victim's Story" (1989) 87 Mich. Lul. 2320. at 2327.)

The denial of the link between vicious acts or vicious speech and an overtly racist or sexist animus or agenda is both typical and disturbing. It is difficult, if not impossible to develop appropriate responses to violent words or conduct when the debate centres, not around responses, but around the validity of claims to the existence and nature of such violence. 
This paper is about violence against women ${ }^{4}$ in law faculties. I will be discussing the situations of both women who teach and women who are students. Women in law school, like women in engineering, are pursuing careers in an area which was once exclusively a male domain and which remains dominated by men at every level'. While the presence of women in professional faculties is celebrated as a sign of tolerance and equality in our society, the reality for these women is less equal and much less tolerant. Their presence is a daily challenge to male dominance. "It is a challenge which is sometimes met with violence.

Just as violence against women is one of our socicty's most serious and pressing problems, violence against women in law faculties is one of the most serious problems facing those institutions. Because it is members of the legal profession who will be called on to legislate against, prosecute and judge those who commit acts of violence against women outside of law faculties, it is of crucial importance that the institutions themselves begin to address the forms of violence which occur within their classrooms and corridors.

4. I deliberately refer to violence against women and not to an "anti-feminist" backlash. "Anti-feminist backlash" implies that what occurs is a response to a political position or against political activists. The kind of violence I discuss in this paper is anti-woman and not necessarily anti-feminist. The fact that the label "feminist" is often applied to women who verbalize their specific experiences of their environment says more about the labellers than about those who are being labelled. For Marc Lepine, women who chose to study engineering were feminists. By the sime criteria, all women in law would be "feminists." The term feminist can be used, as it is in "anti-feminist backlash" to create a conceptual distance between violence and hatred and the women who are its targets.

5. Women in professional faculties such as law and engineering are, of course, not the only targets for abuse: "sexism and acts of violence against women are commonplace at all of Canada's postsecondary institutions." (M. Bryson, "When sexism stalks the campus" Gilobe and Mail (27 November 1990) A21. Events such as the ones which will be discussed in this paper have been documented in all university departments and faculties. See: Outrage File: Male Violene' Against Women on! University Campuses. Ontario Campus Men's Conference, Malerials prepared by V. Horn and L. Alexis, OCUFA Staff. November, 1991. (On file with the author).

6. The Report of the Ad Hoc Committee on Gender Related Policy of the Faculty of Law of the University of New Brunswick readily concedes this point: "Like the law itself. legal education in New Brunswick has reflected a white, male tradition: the laculty's curriculum. structure, and pedagogical styles arise from the interests. expectations and values of men of a certain social class and race." (Sirre'y /99/ Report, p. i). While in some (though by no means all) law faculties, the male to female student ratio is nearly equal, the legal profession itself remains heavily male dominated. Thus, an overwhelming majority of law professors, judges, and senior lawyers are male. (See, in general, C. Menkel-Meadow, "The Comparative Sociology of Women Lawyers: The "Feminization" of the Legal Profession" (1986) 24 Osgoode Hall L.J. 897.) Assertions of numerical equality misrepresent a significant inequality in the structures of power within the law and its institutions.

7. The "threat" to male dominance is often simply the fact of women competing for the same johs after graduation: "Elspeth Baugh, the Dean of Women at Queen's University says there is a mounting sense of frustration among young men at the attention paid to women's rights. They worry there will not be jobs for them when they complete their studies." (C. Motherwell, "Just saying no doesn't always work" Glohe and Mail (6 November 1990) A8. 


\section{THE INCIDENTS}

I will use a series of incidents to initiate the discussion of violence against women in law schools. By doing so, I hope to give the reader a direct and immediate sense of the kind of event which I will argue constitutes violence. My approach includes intimidation which alludes to specific forms of violence against women. The events are commonplace in the sense that they are not out of the ordinary. That does not make them any less disturbing. I have omitted to refer to the location of any of these incidents, (except where it has become public knowledge), because I do not wish this paper to be a condemnation of specific institutions. It is my argument that the phenomenon of violence against women in law faculties is universal. The existence of such violence does not depend on the institution, although the way in which it is handled most certainly does. The sources for these incidents include events known to the author, events narrated to the author by women law students and professors in Canada and the United States, and events made public through newspaper reporting.

1. A male student informed a female colleague that the male washrooms were full of sexist graffiti. The Women and the Law group at the law faculty decided to investigate. Late one night they toured the men's washrooms and photographed some of the segments of graffiti. These photographs were blown up and made into small posters which were pinned up around the law faculty to protest the violent and derogatory graffiti. The message of the posters was that this violence represented "an attitude that doesn't go away when you close the bathroom door." Examples of the graffiti included so-called jokes such as "Why does the women and the law wench cross the road? To get to the fire hydrant on the other side"; homophobic and sexist accusations such as "you are a shemale"; derogatory graffiti about a fictional "beauty" contest between two of the female professors at the faculty; and references to an issue of Penthouse which was banned in Canada because it depicted oriental women bound, gagged and hung from trees - the graffiti suggest hanging Women and the Law women from trees. The postering caused an uproar in the faculty. Ironically, one unknown student called the police complaining that the Women and the Law group was guilty of "obscenity" for putting up the posters. Following the incident, the faculty had the male washroom painted to eliminate the graffiti. ${ }^{8}$

x. Male washroom pornography in the law faculty at Queen's University was also documented by Sheila McIntyre. McIntyre wrote:

What is significant to me is that although about ten male professors are described in insulting ways, they are denigrated for their teaching or their lack of intelligence. Conversely, three women professors are insulted, but only in sexual terms. We are named and cartooned naked, portrayed as sexually repugnant; or we are the object of speculation about our sexual activities or orientation. . .

Nor was the pornographic objectifying of women faculty buried in the context of dozens of other sexual entries about women. Aside from the three women professors, only three other women appear in perhaps 400-600 entries. A woman staff member was the object of a non-sexual joke. A woman (first name only) is the object of several heterosexual fantasies. And a woman student (full name stated) who is openly feminist is described as a castrator who collects penises. I show up as Z's wife and as a lesbian: "Sheila McIntyre sucks clits and tits." You try walking into a classroom feeling 
2. A first year criminal law class came to the subject of rape. The male professor decided it was a "good" topic for a lively class discussion. The discussion became boisterous and out of hand. Responding to what she felt were derogatory comments about women and sexist attitudes towards rape, one actively feminist student put up her hand to address these concerns. When it became clear that she was expressing feminist views, one of her male colleagues turned to her and told her to shut up. In a loud voice he said: "You're just jealous because you're too ugly to be raped." The professor did not censure the male student, nor did he control the discussion. ${ }^{9}$

3. Following one law school's annual law students' satiric cabaret, two women students expressed their view in the school newspaper that several of the skits presented had been sexist and derogatory of women. Writing in response, six male law students signed a letter which accused the women of being man-hating lesbians. ${ }^{10}$ When one of the women ran for election to the law student government shortly after this incident. her campaign posters were defaced with derogatory, anti-feminist remarks. She was not elected.

4. A senior student prepared a "case" for a first year mandatory moot court competition. The case was approved by a member of the faculty. While the student had simply been directed to prepare a case in the field of criminal law, he had chosen the subject of rape. The case featured a female rape victim who was depicted as being dressed in an overly provocative way and behaving in a lascivious manner towards the "accused." The issue in the problem was whether, given the behaviour of the woman, the accused could be said to have a reasonable belief in consent. First year students complained about the offensive characterization of the woman and the way in which the problem contributed to harmful stereotypes about rape. They circulated a petition calling for a retraction of the problem. The petition was signed by a majority of the students in the law faculty, both male and female. It was determined that, for academic purposes, it was "too late" to withdraw the

human when you know sixty pereent of the student population may have read such entries, may find them amusing or the ultimate insult, and the words stay on the walls. (S. McIntyre, "Gender Bias Within the Law School: "The Memo" and its Impact" (1987) 2 Can. Jo. Women and the Law' 362 at 369. 383-84).

The woman student considered completing the course on her own without attending any further lectures. The fact that the subject of rape is often handled badly in criminal law classes has been pointed out by several authors. See: McIntyre, ibid. at 381: E.M. Schneider, "Task Force Reports on Women in the Courts: The Challenge for Legal Education" (1988) 38 Jo. Legal Ed. 87 at 90: N.S. Erickson. "Sex Bias in Law School Courses: Some Common Issues" (1988) $38 \mathrm{~J}$ o. Legal Ed. 101 at 114-5; M.I. Coombs, "Crime in the Stacks, or a Tale of a Text: A Feminist Response to a Criminal Law Textbook" (1988) 38 Jo. Legal Ed. 117 at I31; F. Seidenberg, "A Neglected Minority - Women in Law School" (1986) 10 Nova L.J. 843 at 845; K.B. Czapanskiy and J.B. Singer. "Women in the Law School: It's Time for More Change" (1988) 7 Law and Inequality 135 at 138. One Gender Committee report observed that faculty members are "too inclined to use sexual assatult cases for teaching purposes." (C. Amendola. "Gender Equality Committee releases report" Ohiter Dicta, Osgoode Hall Law School. Monday, February 5, 1990, Vol. LXII. No. 16.

The "dropping out" or avoidance of classes by silenced women students has also been observed by S. McIntyre, supra, note 8 at 381 .

10. The lelter was printed without comment by the newspaper. 
problem. The furor over the problem reached the city press. The assigned case was described in the newspaper, and both the Dean of the law school and the author of the problem were interviewed. The Dean regretted the distribution of the case and stated that an inquiry was being made." The student was unrepentant. In spite of the petition indicating that most students, malc and female, objected to the problem, he was quoted in the paper as saying that the uproar was orchestrated by only a few radical lesbian feminists. ${ }^{12}$

5. A Women and the Law group had trouble attracting members because of the stigma attached to open identification with women's issues within the law faculty. Posters advertising Women and the Law events and speakers were routinely defaced or torn down. The Women and the Law notice board was often vandalized, and the group had to request a locking glass front for the notice board.'

6. A group of male students in a first year constitutional law course taught by a woman regularly planned to intervene in class. Their object was to distract the professor from the topic and to fluster her. Since she had the reputation of being a feminist, they took particular pleasure in "baiting" her in this respect to see how upset she would become. ${ }^{14}$

11. This incident did have the positive effect of raising consciousness within the faculty as to problems of gender bias. A committee was established to develop guidelines for the setting of exam and moot hypotheticals.

12. The use of sexist hypotheticals is generally acknowledged as a problem. (sec. for example, P. Williams. The Alehemy of Race and Rights (Cambridge. Mass: Harvard University Press. 1991) ch. 5). That such hypotheticals sometimes go beyond harmlul stereotypes and contain ugly and demeaning language or descriptions is not uncommon. One law student brought to my attention a hypothetical describing an argument between husband and wife in which the husband calls the wife "a fucking cunt." (From a statement by a woman law student. (On file with the author.))

13. The defacing of Women and the Law posters and notice boards is also a common occurrence. One student noted that women law students were also reluctant to altend Women and the Law meetings "for fear it will hurt their chances of getling a job with a conservative firm. When you point out the fact that they don't have to put anything on their resumes about it. they look at you and say. "It's a small world. They'll find oul."' The New Brunswick Law Faculty Report on Gender Related Policy noted that: "The second shortcoming revealed by the survey is a disturbing level of anti-feminism. Over half of the women and a third of the men experience some pressure from other studemts not to be or act seriously concemed about women's issues and rights. Almost half of the women and a third of the men often hear other students express derogatory or sexist comments about feminists." (Survey /99/ Report. p. ii).

.4. A similar incident is described by Sheila McIntyre. In her memo. she describes two "explosive" confrontations which occurred in her classroom in the course of the year. In one situation. a group of male students "mutinied" in a class in which she altempled to introduce a gender perspective into a hypothetical for class discussion.

The details of what happened in class are difficult to describe. About six men were deliberately disruptive, unco-operative, interruptive, and angry. To my surprise. they endorsed the propositions outline D above and belligerently tried to prevent students who disagreed with their position from speaking, by a combination of insult, interruption. hostile gestures, and increasingly voluble but untenable argument. When I tried to legitimize the contributions of other students, they were ecpually abusive to me. Their bottom line, albeit only indirectly conveyed, was: "we do not want to talk about gender, and we will not and we will not let anyone else talk either." (Mclntyre, supra, note 9 at 375-76.) 
These events are merely a sampling. Where the attacks involve graffiti, the women are generally accused of being lesbians. ${ }^{15}$ Members of Women in the Law groups are often ostracized for being man-haters and lesbians. Where the group is particularly active. membership tends to dwindle to a few strong voices who become outcasts within the law faculty. The making of sexist remarks by professors in classrooms has been widely documented, and the silencing of women students to which it contributes is the subject of a great deal of discussion. ${ }^{16}$

Events such as those described above are relatively common and their occurrence is generally unquestioned. What is a source of debate is the interpretation to be placed upon them: What do the incidents mean? What is their place within a wider pattern of sexual discrimination and harassment? I argue that the place for these incidents is within the context of violence. The subject of violence against women is too often fragmented: Pornography is considered an issue of freedom of expression. Abortion is seen as a moral issue; incidents like the killings at the Ecole Polytechnique are seen as "senseless": the treatment of women in law schools is given the ironic name of silencing.

This paper suggests that the described incidents are part of a recurring motif in the pattern of violence against women which is woven into our society. The argument is not that law schools are the source of male violence, nor is it that men in law are any more or less violent than men in any other job or profession. The argument is that there is a problem in our society: it is a problem called violence against women. ${ }^{17}$ It is a problem which is large, frightening and possibly out of control. It is a problem which has many manifestations; it is not limited to any particular social class or generation. As a "minisociety," the law school community must come to terms with the reality of violence against women between its own walls.

\section{VIOLENCE}

Violence is an important concept for the discussion of women's experience in the contained environment of a law school, as well as in larger society. For most women. violence is something which is both feared and familiar. Much of the silence surrounding the perpetration of acts of violence against women has been recently broken. Increased media and political attention has been given to sexual assault, sexual harassment, child sexual abuse. and spousal abuse. Taken together, these forms of violence speak of a troubled, if not sick, society where women of all ages and backgrounds face fear and

The Osgoode Hall Law School Gender Committe hats also reported "overt hostility from some white, male students who caricature feminists, denigrate female faculty and attempt to silence alternate theories with secming impunity." (Amendola. sıtpra. note 9).

15. Homophobia, which. although related, is a whole ficld of incuiry of its own, is also manifested in attacks on gay/lesbian notice boards.

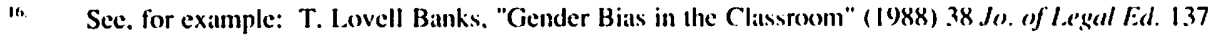
at 144-45. where she gives statistics on the use of offensive humour by law professors. See also, in general. the series of articles in (1988) $38 \mathrm{Jo}$. Le'gal Ed. all 1-195.

17. Matsuda argues that "Violence is a necessary and inevitable part of the structure of racism." (stupurt. note 3 at 2335). Violence is, in fact, a "necessary and inevitable" part of all forms of domination. including the domination of men over women implicit in sexism. 
harassment at home, at work and on the street. Yet even as we begin to speak about violence against women, it becomes fragmented, dispersed and diminished by the categories we give it. ${ }^{18}$ The violence directed by men against their wives and girlfriends becomes "domestic violence," or "date rape." The violence faced by women in the workplace is "sexual harassment." The killing of fourteen women students becomes a "random act" of a madman. By dividing and separating the problem into categories, syndromes, and catch phrases, we somehow lose the connections. The problem seems smaller, more contained. It is like conceiving of a forest fire as a series of burning trees.

Violence against women has many forms and many manifestations. It is at once a social attitude and the manifestation of that attitude. Violence is not an easy term to define. It is usually defined in terms of its effects. For most people, any act producing even a small amount of blood is violent. Sometimes damage to objects is accepted as a violent expression of anger or hostility against a person (as when someone vandalizes another's car or defaces the walls of a house with slogans).

It is significant that the Criminal Code, which one might assume to be the "bible" of the control of violence in society, offers no definition of violence. It is, surprisingly, perhaps the most "assumed" term within the entire Code. Offences which one might consider the most "violent" of all crimes, such as murder and assault, do not mention violence. Rather, they talk about concrete, measurable things like "death" and "bodily harm." The only Criminal Code provision which uses the term violence is s. 423 which deals with the crime of "intimidation." Since the relationship of violence to intimidation is an important aspect of the discussion in this paper, I will reproduce the provision here:

423. (1) Every one who, wrongfully and without lawful authority, for the purpose of compelling another person to abstain from doing anything that [she] has a lawful right to do, or to do anything that [she] has a lawful right to abstain from doing,

(a) uses violence or threats of violence to that person or [her] spouse or children, or injures [her] property;

(b) intimidates or attempts to intimidate that person or a relative of that person by threats that, in Canada or elsewhere, violence or other injury will be done to or punishment inflicted on [her] or a relative of [hers], or that the property of any of them will be damaged,

$\cdots$

is guilty of an offence punishable on summary conviction. ${ }^{19}$

1x. bell hooks makes the point that terminology which "categorizes" violence can exclude from discussion and contemplation acts of violence which do not fit that label: "A distinction must be made between having a terminology that enables women, and all victims of violent acts, to name the problem and categories of labeling that may inhibit naming." (b. hooks, "violence in intimate relationships: a feminist perspective." in Talking back: thinking feminist, thinking black (Boston: South End Press, 1989) at 89.)

19. R.S.C. 1985, c. C-46. 
I am not using s. 423 to argue that the provision should be used to charge law students, or that this provision would even be useful in challenging the kinds of violence which society directs towards women. I am using it, rather, as a window through which to look at how the law regards violence - at whether the law itself - as taught within the law school classroom - recognizes the kind of violence which I will discuss in this paper. The silence/ambiguity of the law regarding violence against women is part of the problem of violence against women in law schools.

In s. 423, the injury or "effect" to be prevented is not "death" or "bodily-harm," it is intimidation. The effect of intimidation consists of being compelled to do something or to abstain from doing something. The same effect - causing someone to act $-\mathrm{can}$ be produced in many different ways: parents compel their children to do or not do certain things. We all have, in our relationships with others, tried to compel another person to do or not do something: we call it persuasion. The crime of intimidation is not simply about compelling people to do or not do certain things. The modification of behaviour which is the effect of this crime, is intimately linked to the nature of the "persuasion" used. It is intimately linked to violence - specifically "violence or threats of violence."

Presumably the classic case under s. 423 - the kind of case for which the provision was probably designed - involves something like A wanting to sue B and B threatening to beat him up (or rape his wife, or kill his children, or whatever the B's of this world threaten to do) should $A$ initiate a law suit. Since $A$ has a lawful right to demand his lawful rights (that is, to sue B), B will be stopped by the law from intimidating A.

The kind of case I am more interested in within this paper looks very different from this. In my scenario, A wants to contribute to a classroom discussion in law school. The discussion is about something she feels strongly about - let us say sexual assault. But because of the past and present conduct of $B$, she fears that if she says what is on her mind, B will heckle, or insult her in front of the class, or B will write "lesbian" over her student council campaign posters, or B will write some ugly sexual slander about her on the men's washroom walls. A is definitely intimidated, but do B's past behaviour/attitudes constitute a threat, and do the proposed acts constitute violence?

Let us look at the problem first from the angle of the "lawful right." Does A have a "lawful right" to participate in classroom discussion? Or is it a privilege, based on a long line of privileges which got her into law school in the first place. Participation may be defined as a choice and not a right. Considering the history of women in law school starting with the original "lawful" exclusion of women from such schools, it can be said that the presence and participation of women in law classrooms is not just a lawful right but one which was fought for against the law itself. It is "lawful" in the sense that it is full of law. The presence of women in law faculties, and in the legal profession in general, is a right wrested from the law.

The above digression was made because I believe it necessary to stress the importance, in terms of women's rights, of the presence - the vocal presence - of women in law school. It is a woman's lawful right to be there. Her voice in law school is crucial to the exercise and expansion of that lawful right and other lawful rights in society. 
In my second hypothetical, I ask whether the past behaviour/attitudes of B can constitute a "threat." Threat is another one of those words not defined by the Criminal Code. Rather, the word appears to receive its content from the nature of what is threatened. Thus "I will kill you" is a threat because killing is a crime. Similarly, "I will beat you, burn down your house, wreck your car" are threats because the damage to persons/property they involve are all crimes. Threats to deface campaign posters or write defamatory graffiti are a little more "iffy" just as those "effects" are considered more "iffy" in criminal law. Threat also has an implied content of being manifested in a physical or vocal way. Is past behaviour a future threat? Can a threat be general (directed at a group, such as "women") and not specifically directed at an individual? Does a threat require a specific threatener? That is, does A have to know that B will do something to her, or is it enough that she knows that some anonymous member of her class, somewhere from B to $\mathrm{Z}$, will undertake some hostile act in response to her classroom participation? What if the environment is such that she believes something will happen, even if it does not? Does a threat have to be carried out every time to remain a threat? What happens if women simply come to believe that it is "risky" to speak up in law school classrooms?

This problem of "threat" is a very important one. Women often say they feel threatened. The feeling that threats can exist in the atmosphere of a place is what keeps women from walking alone on the streets at night, from using parking garages, and from identifying themselves on their answering machines. This kind of threat is not recognized by the criminal law, yet it is a threat of violence which keeps women from doing what they have a "lawful right" to do.

Violence is at the centre of this tangle. Violence is what is threatened. It is what comes between a person and her lawful rights. Rape, murder, assault are all generally considered to be pretty good examples of violence. Justice McLachlin of the Supreme Court of Canada has accepted the Shorter Oxford English Dictionary's definition of violence. Thus, violence is " $[1]$ he exercise of physical force so as to inflict injury on or damage to persons or property. ${ }^{20}$ She then goes on to confuse the issue of threats and their object of violence by adding that violence "connotes actual or threatened physical interference with the activities of others." 21 The Oxford definition makes violence look like bodily harm (or property damage); the addendum makes violence look like the crime of intimidation.

The confusion over the meaning of violence is perhaps only confusing from a legal perspective. Threats of violence are violence itself. Those who are threatened know that the violence they fear has already begun with the threat. The threat is a taste of violence and a promise of more. It is the slap that foreshadows the beating. 
Women are profoundly aware of the level of violence directed at them as women.22 Women who resist men, who defy them, outsmart them, out-earn them, who challenge them, question them and, on top of it all, do not serve them coffee or dinner-on-time are beaten, raped and killed for their insubordination. Women know this can happen - this is why we are shocked but not surprised by the tragedy at the Ecole Polytechnique. Graffiti in washrooms, heckles and taunts, sexual objectification and other forms of abuse are not rape, battering or murder. But they occur as a result of the same "stepping out of line," the same assertions of individuality and originality which trigger those other forms of violence. They are threatening to women because they are threats. They are violent.

Graffiti, heckles or comments which pornographize or sexualize women, or which mention rape outright have a particular impact. It is no secret to men that women live with the fear of sexual assault. Because of the daily reality of such fears (we do not walk alone at night, we are uncomfortable using the libraries late at night, we are uncomfortable in deserted locker areas or corridors after certain hours), it would be difficult to argue that heckles, comments or graffiti which sexualize women are not a direct allusion to sexual violence against women. The reason why pornographic graffiti, or the use of ugly sexual terms, is intimidating to women is not because we are more easily shocked by unladylike language or images. Rather, we are intimidated because such words and images are taken as allusions to a very real and devastating kind of violence. We are responding to threats of sexual violence.

In this paper, I will argue that $A$ 's reluctance to speak up in class is rooted in a fear of violence which is based on threats manifested in acts of heckling, graffiti, and a range of other activities. It ultimately does not matter whether the law thinks of such things as violence - after all, this is about violence in the male dominated breeding ground of law - the law is not objective, nor is it "innocent."

The kind of violence described by the "incidents" is unbloody. ${ }^{2.3}$ While it may involve threats, there is no actual physical force used against women. Nobody bleeds. Yet what occurs is violent because it constitutes an illegitimate consiraint on human will. I consider the incidents I talk about to be violent because they use implied threats of physical or sexual violence to restrict the activities of women and to silence them. In some cases, the

This is evidenced by the strong reaction of women in interpreting the tragedy at the Ecole Polytechnique as a manifestation of general societal violence against women.

"3 It is worth considering the class-based approach to racist i iulence described by Mari Matsuda: "Lower- and middle-class white men might use violence against people of color, while upper-class whites might resort to private clubs or righteous indigniation against "diversity" and "reverse discrimination." (Matsuda. supro, note 3 at 2334). While the argument is different, the point is nonetheless interesting. What Matsuda does is identify clan based differences in response to the same animus: racism. While the lower classes respond with attual physical violence. the upper classes have more "cloaked" responses. It is possible that the privileged individuats attending law school have been socialized to more "bloodless" ways of mantesting hostility than outright physical violence. This would suggest that the most important factor is the animus (whether racist or sexist). The next step would then be to recognize the range of manife valtons of this animus. 
fear engendered by such behaviour may cause women to leave law school. ${ }^{2+}$ While the incidents described in this paper may not be considered as "true" violence by the men who participate in them or who tolerate them with a shrug, the fact remains that they are perceived as violent by the victims. In describing her experiences as a law professor at Queen's University, Sheila McIntyre wrote: "The recognition/recollection that I had experienced some of the events documented as forms of sexual violence was a crucial insight for me that helped account for the fear I and other women had about going public with my story. ${ }^{25}$ Although she was not physically harmed, McIntyre's experience of the behaviour of her male students was one of violence. The "mark" of this violence was her fear of articulating it. In fact, much of the violence against women in our society is manifested not through the blood of the victims but through their fear and their silence. ${ }^{26}$ Sociologist Elizabeth Stanko notes:

\begin{abstract}
Understanding what it means to be female within contemporary British and American societies is understanding the meaning of male violence in women's lives. Many women's lives, in fact, revolve around strategies to avoid men's threatening, intimidating, coercive or violent behaviour. ${ }^{27}$
\end{abstract}

Stanko refers to such threatening behaviour as "physical and/or sexual terrorism." ${ }^{28}$ In a similar vein, Catharine MacKinnon writes that: "Sex abuse ... is a terror so perfectly motivated and systematically concerted that it never need be intentionally organized - an arrangement that, as long as it lasted, would seal the immortality of any totalitarianism." ${ }^{29}$ Intimidation is the terrorism of violence. The threat and the act are parts of the whole of violence. Where a threat of violence can silence as effectively as an act, then they are truly inseparable.

The same conditioning of behaviour in response to threats and hate speech has been observed with respect to racism. Matsuda writes:

Victims are restricted in their personal freedom. In order to avoid receiving hate messages, victims have had to quit jobs, forgo education, leave their homes, avoid certain public places, curtail their own exercise of speech rights and otherwise modify their behaviour and demeanor. (Matsuda, supra, note 3 at 2337).

25. McIntyre, supra, note 9 at 368.

36. Sce for example: Ingrid Peritz. "Slayings not part of trend. analysts say," Montreal Gazente (9) December 1989) A3: "Still, studies show Canadian women live in daily fear of physical and sexual violence. A report made public in June said 56 per cent of urban Canadian women feel unsafe walking alone in their neighborhoods after dark." See also: Jack Todd, "Reliving the terror of a date with a 'nomal' guy" Montreal Gazette (9 December 1989) A3.

A report of another incident on a university campus explicitly referred to the silencing of women. The report concerned an incident where vandals: "plastered tampons on the doors of women professors" and wrote a letter denouncing the women's studies programme. These incidents were said to have "created an intimidating atmosphere for women at the University of Lethbridge." ("University of Lethbridge women silenced" Calgary Herald (14 April 1991) A3).

27. E.A. Stanko, Intimate Intrusions: Women's Experience of Male Violence (London: Routledge \& Kegan Paul, 1985) al 4.

:x Stanko, ibid. at 9.

29. C. MacKinnon, Feminism Unmodified: Discourses on Life and Law (Cambridge, Mass: Harvard University Press, 1987) at 7. 


\section{SILENCE AND VIOLENCE}

The litany of incidents like those described above could easily be longer. Such phenomena are widespread and well known among women students and professors. With the exception of Sheila McIntyre's memo, the problem is rarely addressed as one of violence. Usually it is spoken of more neutrally as the "silencing" of women students. While the act of silencing in itself may be a very violent one, the connection between such silencing and violence is seldom made. Silencing is depicted as something male law professors and students do inadvertently, because they do not know any better, or it is something which occurs because women's "difference" is not being accommodated. For example, one woman attributes silence to a kind of "alienation": "They remain silent because they believe their views carry no weight. They are silent because they believe that women are largely ignored or invisible in law school classrooms. The feeling of alienation is often reinforced by the use of sexist textbooks and sexist language." ${ }^{\text {"30 }}$ In a similar, though somewhat more patronizing vein, James R. Elkins attributes the same silence to women's difference: "Women's silence in legal education is rooted in the 'strangeness' of legal language which divorces the language of the law from the 'human sensitivity' associated with women's experience of and in the world. Law school fails women because it ignores women's experience. ..."31 This type of "rationalization" of silence depicts the gentle sex as baffled and bemused into silence by the ever-somasculine logical firmness of law as an abstract study. It is not the law, however, that keeps women silent - most women law students have plenty to say about the law and about their experience of it. It is the law school, the classroom, the male students and professors who must be looked to for the reasons for women's silence. ${ }^{32}$

The silence of women in law is rarely described as a function of violence,,$^{33}$ although the act of silencing itself is loaded with violent implications. On the "other" side of law, to "silence" someone is to kill her. Guns that can be used to kill without noise use "silencers," but it is not just the gun which is being silenced. The definition of the verb "to silence" is also full of muted violence: "reduce to silence, as by restraint or

Stupra, note 16 at 139.

J.R. Elkin, "On the significance of Women in Legal Education" (1983) 7 ALSA Forum 290 at 306. Note that Catharine MacKinnon has little patience for these kinds of arguments based on difference:

Women value care beciase men have valued us according to the care we give them, and we could probably use some. Women think in relational terms because our existence is defined in relation to men. Further, when you are powerless, you don't just speak differently. A lot, you don't speak. Your speech is not just differently articulated. it is silenced. (Supra, note 29 at 39.)

3. To say it is not the law but rather the male-dominated institutions of law which silence women is to shift the focus from the particular "nature" of women to the concentration of institutional power in the hands of men. The relationship of power to domination, coercion and other forms of oppression is crucial here.

3.. $\quad$ S.M. Wildman does describe silencing as a form of violence. She writes, "We are often complicit in the silencing of students: as students and as professors we watch the verbal violence that occurs in some classrooms and yet we remain silent." ("The Question of Silence: Techniques to Ensure Full Class Participation" (1988) 38 J. Legal Ed. 147 at 148). 
prohibition; repress, . . . stop (enemy guns, etc.) from firing by destroying or disabling with return fire.".34

In their article "The Legal Education of Twenty Women," Catherine Weiss and Louise Melling not only blame silencing on what they call women's "alienation," they explicitly refute any suggestion of violence:

\begin{abstract}
Although law school is a violent institution insofar as it perpetuates a legal system that does not take seriously the words of a rape victim. the bruises of a battered woman. or a girl's accusation of incest, it does not perpetrate such violence against women-students during liheir education. Thus we speak primarily of difference, in order neither to exaggerate the violence of the law school toward womenstudents nor to detract from more severe forms of violence against women."
\end{abstract}

In making this point, the authors suggest that law school, as an institution, is violent towards women "out there" but is a neutral environment for women law students. This implies an unreasonable division between women "inside" and women "outside" - a division which does not exist for the woman law student. Further, the "system" which "does not take seriously the words of a rape victim" cannot be wholly separated from the individuals who dominate it. The attitudes in society which produce violence against women are the same which motivate judges, lawyers, legislators and law students to dismiss it. The "system" cannot be so conveniently distanced from its constituent parts. Blaming the anonymous "system" avoids placing blame more directly on those who control, dominate, support and inhabit it.

Weiss and Melling regard alienation as the root of the problem itself, not as a symptom of deeper violence. This "interpretation" seems to be quite widespread. Many women (and some men) have written about the silence of women in law school classes and have suggested that it stems from the supposed inability of the women to relate to the maledominated environment of law school. These authors generally argue that the law school should adapt to become a more hospitable environment for women. This assessment is fraught with disturbing implications. It trivializes the "silence" of women by suggesting it can be remedied by simple structural changes. It suggests that the silence is a problem akin to shyness which needs only compassion and coaxing to be overcome. By rooting the problem in women's "difference," it places the focus of the inquiry on women. Not only does it emphasize women's difference, rather than their supposed equality, it turns attention away from the behaviour of the men within the law school environment. To rationalize this violence by calling it "alienation," "misunderstanding" or "competition" focuses the attention on women and their "difference." It blames the victim by not blaming the perpetrator. MacKinnon writes: "That word [alienation] abstracts her

3. The Gage Canadian Dictionary (Toronto: Gage Educational Publishing Limited, 1973) at 1025. Consider also Mackinnon's discussion of the "silencing" of women who are involved in the pornography industry: "Once these things happen. the women are silenced forever, so it"s impossible to be both a victim and a survivor. The deepest victims of sexism are the ones you never hear from again." (Mackinnon. supra, note 29 at 131.)

35. C. Weiss and L. Melling. "The Legal Education of Twenty Women" (1988) 40 Stanford L..J. 1299 at 1300 . 
experience but begins to convey the out-of-it-ness that one needs to survive torture. ${ }^{\text {"36 }}$ If the silence of women in law school is to be regarded as "alienation," such alienation must be considered as a symptom of something deeper. As Adrienne Rich has observed, "In a world where language and naming are power, silence is oppression, is violence. ${ }^{37}$

Weiss and Melling have made the dangerous (though perhaps understandable) assumption that reality cannot penetrate the walls of a law school. There is absolutely no reason to believe that the misogyny which lies behind so much of the violence against women in our society is absent from law faculties. While it is one thing to say that rape, incest and wife battering are more "severe" forms of violence than those which I will document, it is highly problematic to call them more serious. It is not the degree of injury to the victim which should be the focus of attention; it is the phenomenon of violence itself.

\section{VIOLENCE AND THE SEXUALIZATION OF WOMEN}

Women in law schools are often "sexualized" as a means of delegitimation, domination and control. It is an effective and devastating means of attack: not only does it sever women from their reasons for being in law school (their intelligence, their ambitions, their "self") by negating their minds and exposing their bodies, it carries with it the unspoken threat of greater sexual violence, of exposure, physical harassment and rape.

In almost all of the incidents described above, women are attacked at the level of sexuality. They are either treated as the objects of male fantasy, as the potential targets of sexual violence, ${ }^{3 x}$ or they are characterized as lesbians ${ }^{34}$. The sexualization of women is both a form of violence against women and a means of communicating male power. Women in law schools, who have chosen to make their arguments with words and through reason are often shocked to have their voices silenced by the sexualized attacks of their male colleagues. On the intellectual level, the statement "you are just a lesbian" is an inadequate and irrelevant response to a reasoned argument against the sexual stereotyping of women in course materials. However, on the level of day to day life, it can be silencing. Sheila McIntyre observes:

Perhaps because women struggle so hard for intellectual and professional acceptance and credibility in male-dominant contexts, we find it shattering to acknowledge how much we are sexualized and how much of our intellectual/professional denigration carries sexual resonance. Masculine ego gratification in putting women - especially women with (some) power - down is sexual in a culture which eroticizes the subordination of women."

36. C. Mackinnon. supra. note 29 at 128.

37. A. Rich. On Lie's. Secrets and Silence: Selected Prose': 1966-78 (New York: Norton, 1979) at 204.

3x. As in the washroom graffiti incident. the rape discussion incident. and the moot problem incident.

34. As in the cabare incident and the moot problem incident. The use of the term "lesbian" as a form of attack is complicated by the fact that it illustrates homophobic tendencies. Such tendencies are a disturbing neality which go beyond the scope of this paper. 
The kinds of male fantasies which are expressed in the incidents outlined above are not ones of romance or of consensual sexual activity. They rely heavily on the idea of male domination of the woman. The depictions of bound and gagged "women and the law" women in the washroom graffiti incident are the sharpest example of a male fantasy of violent sexual domination. The incidents where women are sexualized tend to involve women who have declared themselves feminists or who have taken a "feminist" on an issue. This manipulation of sexuality to debase, degrade and assert power over women who have attempted to speak out is not just a disturbing commentary on male sexuality. It is also an indication of the violence inherent in the sexualization of women law students and professors through graffiti, heckles, skits and jokes.

In the event that women are not already concerned about the potential for sexual violence in the community outside the law school, male law students seem prepared to provide reminders. Anonymous graffiti is often explicitly sexual and violent (such as the bound and gagged women in the washroom graffiti incident). The treatment of issues of violence against women in criminal law classes can also remind women of their vulnerability, particularly where stereotypes of rape victims, like the one in the moot problem incident, suggest that women "ask for" rape. Silencing women's voices on the subject of rape reminds them that they have no control either over its occurrence or over the terms by which it will be judged. A comment such as "you're too ugly to be raped" is particularly appalling. It implies that women who seek the approval of attractiveness seek rape; that ugliness equals exclusion, but that inclusion is a form of consent to sexual assault ${ }^{42}$.

The label of "lesbian" is meant to connote deviance from a norm which is established by a powerful male hierarchy. Because lesbians reject male sexual dominance, they are the ultimate dissidents. Yet the label, when used by men in this manner, is not meant to indicate that these women have rejected male domination. Rather, it is a label of failure: the ultimate in male approval has been withdrawn. Thus, the women called "lesbians" are not ones who have chosen to be with other women, or who have chosen to reject men; they are ones who have been rejected by men because they are not attractive. In the scale of value accorded to women, they rate a flat zero. This is the censure which is inherent in the type of comment indicated in the rape discussion incident: "you're too ugly to be raped."

The label of "lesbian" is not applied to any and every female law student, nor is every woman law student targeted by jokes, heckles or graffiti. The sexuality of women is used as a means of control and manipulation. General reminders of the potential for sexual violence may serve to curb the activities or participation of most women students. More specific attacks are levelled at those who are too vocal and, thus, providing a warning to

11. Speaking out about issues seen to be of specific concern to women is generally enough to be given the label of "feminist." In the world of misogyny, any open identification with the concerns or status of women is "feminist," as if concern for one's own safety, welfare or equal treatment constituted a political perspective.

12. "Raped women are seen as asking for it: if a man wanted her, she must have wanted him." (MacKinnon, supra, note 29 at 141). 
others not to draw attention to themselves in the same manner. Where women have been conditioned to derive self-esteem both from male approval of their appearance (difficult to separate from sexual approval) and from their ability to limit male access to their "virtue," the denigration of their physical person combined with its publicness is a devastating attack on both fronts.

Catharine MacKinnon argues that what is called sexuality in our society is in reality the politics of male supremacy. She writes:

All this suggests that what is called sexuality is the dynamic of control by which male dominance -- in forms that range from intimate to institutional, from a look to a rape - eroticizes and thus defines man and woman, gender identity and sexual pleasure. It is also that which maintains and defines male supremacy as a political system. ${ }^{+3}$

It would perhaps be naive to expect that "sexuality" as MacKinnon describes it would be absent from law school. Her brand of male-defined sexuality is omnipresent. But what is striking is the way in which aspects of this sexuality are used as forms of manipulation and control in areas supposedly outside the sexual sphere. In the incidents described above, women's sexuality is used as a weapon against their ideas, voices, and actions. It is used against their full and equal participation in law school.

\section{VIOLENCE AND MALE POWER}

Earlier in this paper I argued that the fear and harassment experienced by women in law school were the effects of gender-related violence. I have also argued that the sexualization of women is one of the means by which this violence is perpetrated. The patterns of sexualization of women in law school suggest a directed exercise of male power. While all women in law school may be regarded as objects for the potential sexual gratification of their male colleagues, this would tend to be regarded as "normal." Although not less normal (in the sense of usual), the sexualization of women students and professors through pornographic graffiti and other forms of written and verbal abuse is much more focused. Students and professors who are called "lesbians" are almost always those who speak out on women's issues. Women who assert both their own personal strength and their opposition to male domination place themselves open to attack. The warning shot may be simply words like "lesbian," but the force of intimidation contained in such words comes from an awareness of the arsenal of very real violence which lies behind them.

Incident 6, which involves a female (and feminist) law professor, is a good illustration of the way in which some male students react against women occupying traditionally male power-roles. Professors are in a position of so-called "power" over law students: they control classroom activities, they dictate what students will study, they control workload, they grade, evaluate, and can control the "future" of the student both through grades and

43. C.A. MacKinnon, Toward a Feminist Theory of the State (Cambridge. Mass.: Harvard University Press, 1989) at 137. 
through references. Law professors have traditionally been male, and the dearth of tenured female professors in law faculties in North America underlines the recent and still tenuous inroads women have made in this area.

Incident 6 shows the way in which feminist law professors may be challenged by their students at a level which challenges their competence to teach. In this example, male students plot to turn their constitutional law course into a side show. Any baiting of the woman professor which has the effect of side-tracking her from the content of the lecture is considered a "victory": the person they defeat is the professor who had the nerve to presume she could teach them anything.

Sheila McIntyre's "explosive" classroom experience ${ }^{\text {t4 }}$ shows a more open, deliberate and hostile reaction of male students against the introduction of a "gender perspective" into classroom discussion. The attack was directed against her as a woman. She wrote:

From the front of the classroom, the sexual titillation evidently enjoyed, and the sexual swagger openly exhibited, by the usual small gang of male students who compete with each other to undercut a woman teacher's authority appears identical to that of sidewalk street oglers who by word and gesture pornograph passing women for each others' masculine approval. Even when the language of male hostility is academic rather than obscene, classroom tension is not experienced as intellectual conflict alone: women feel it physically and sexually. We feel sick, numb, bruised, molested, undressed, uglified."

While the hostility to feminist professors in class is directly aimed at them, it can serve as a stark reminder to women students in the class that they will face similar abuse if they defend the professor or express similar ideas. Where women students seek out courses with female professors in order to find support for their own ideas, they may also be served a strong warning against publicly holding those views. ${ }^{46}$

\section{CONCLUSION}

The silence of women in law school has been the subject of much observation and commentary. This silence has been attributed to women's "alienation" or unaccommodated difference. I have tried to show that this silence is in reality the scar left by the violence or intimidation which is directed against women in law school.

4. Described in footnote 15.

45. McIntyre, supra, note 9 at 370 .

46. Sheila McIntyre documented the response of women students in her class to the aggression shown by male students when gender issues were raised in class. She wrote: "Both women felt attacked, shocked and silenced by the Fillipowich class. They no longer felt it safe to speak, and they feared that even if they did raise feminist concems and I validated their viewpoint, I would be targeted for more male student abuse. The more distressed of the two wanted to quit law school.

"A couple of other women in the class appeared and presented a mixed message. On the one hand, they wanted me to know they supported my raising of gender issues and were interested in discussing them; on the other hand, they urged me not to do it again because they were afraid of what might happen (to me or to them was not clear)." (McIntyre, supra, notc 8 at 376.) 
Violence is often defined in terms of its effects. While people are quick to recognize bruises, blood, pain and death as "proof" of violence, the silence of women is overlooked. The violence against women in this society is so pervasive that women have developed ways of dealing with this reality which are as much the signs of the violence they suffer as bruises or blood. These signs may be misinterpreted as "difference." Women are said to be "silent," when in reality they are silenced.

The sexualization of women is one of the most frequent weapons used in this kind of violence. It forcibly separates a woman's body from her mind and leaves her helpless and exposed. The general sexualization of women in society is so common and pervasive that it may be difficult for some to conceive of it as a weapon. But the fact that it is not only a weapon but one which can be consciously wielded and directed can be seen in the way it is used to target individual women who either hold positions of perceived "power" over men or who challenge the male supremacism of law and society.

The general levels of violence against women in society provide the context for the fear that is engendered by directed pornographic graffiti, heckles, "jokes" or labels such as "lesbian." Women in law school share in the general awareness of the constant threat of violence against women in everyday life. Within "everyday" life, women's experience of violence is fragmented. It appears more random, less personal, less focused. Within the law school community, however, as within all other spheres where women are beginning to compete with men for positions of "power," we can see that this violence becomes specific, focused and direct.

One of the many disturbing aspects of the slayings at the Ecole Polytechnique was the gunman's obvious resentment of successful women. His victims were all students in a professional faculty. His suicide note contained a "hit list" of fifteen prominent women in Quebec society. He accused his victims of being feminists and seemed to equate feminist women with those who venture into what was formerly exclusive male domain. This attitude is unfortunately neither isolated nor exceptional:

She [Marie-Andréc Bertrand, Professor of Criminology at the Université de Montréal] noted that the three-page letter written by Lépine and lound on his body alludes to the growing power of feminists power Lépine believed belonged in the hands of men.

\footnotetext{
"Although he may have been extreme in his vengeful actions, he is not alone as a man in being unable to accept that women are gaining in equality." Bertrand said.

"These manifestations of anti-woman and anti-feminist sentiments are all around us."
}

Male anger against women is part of campus life at $U$ de $M$, as on virtually every university campus. Bertrand said. 
"Women students experience aggression, harassment and even violence from male colleagues who are enraged that women are demanding to be admitted into the professions." ${ }^{47}$

This same resentment against successful and vocal women is played out in law schools. It becomes evident when women are kept from joining Women and the Law groups for fear of ostracism or the label "lesbian." It is evident in classrooms where students or professors expressing feminist points of view are heckled or shouted down, or "advised" to stick to "real" law. It is evident in attacks on vocal women in school newspapers and on bathroom walls. The presence of women in law faculties may be tolerated, but their voices as women cannot be raised without fear of reprisal.

Putting an end to this brand of violence requires first that it be identified, acknowledged and condemned. We must stop talking about the alienation of women in law school. We must stop believing that a more "humanistic" approach to corporate law will bridge the gap of women's so-called difference. We must stop believing that violence is something which happens inside cases and outside the law school. The pornographizing of vocal women in law by their male colleagues and students and the slaughter of the women engineering students are incidents on the same spectrum of violence. The silence is deafening. 